\title{
Controlling methods of buildings' energy performance characteristics
}

\author{
Aleksey Jurgaitis ${ }^{1, *}$, Dmitriy Topchiy ${ }^{1}$, Anna Kravchuk $^{1}$, and Daria Shevchuk ${ }^{1}$ \\ ${ }^{1}$ Moscow State University of Civil Engineering, 129337, 26, Yaroslavskoe Shosse, Moscow, Russia
}

\begin{abstract}
The comparison of energy audit regulatory documents results in the great difference of method holding description and the amount of modern energy investigation techniques in domestic and foreign practices. The most common are two methods: thermovision inspection and the Blower Door system. The collation of inspection data proved the necessity of the introduction on a mandatory basis method using Blower Door. The comparison of energy audit holding parameters in Russia, the USA and Europe showed the difference in the structured approach to this problem.
\end{abstract}

\section{Introduction}

The issue of Energy Performance of Buildings is one of the main today, cause not only standard of comfortable living depends on this factor. Since 2016, the criteria for assigning the energy efficiency class to buildings of apartment buildings have been described relatively accurately and clearly, where according to paragraphs 4 and 5 of the second article of law [1], Building Energy Rating is a product characteristic, which reflects its energy efficiency. The question of energy efficiency and energy saving of buildings is a recent problem not only in Russia, but in States of European Union, Africa, Asia and the USA too, where the cost of electricity differs greatly. There are two ways of inspection of the building: energy audit and thermal imaging. The first one is a complex-analytical procedure for detecting defects in the building that affect its energy intensity. The second is to obtain data only on the heat loss of the building with the help of a thermal imager.

On the territory of the Russian Federation energy survey is a voluntary procedure in accordance with Article of law 15 paragraph. 5 [1], except when it is mandatory, for example, when setting into operation or when there is a person with the rights referred to in paragraph 1 of article 16 [1], or for large members of State Energy Register (more than 1500 tons of reference fuel per year). While abroad, the trend is: mandatory energy investigation for corporations and organizations that are Large Consumers of Electricity (LEC, more than 500MWh of personal consuming). The fund formation from taxes for supporting small organizations. As a result -providing a high quality survey to all objects [4]. By that, the interest to education in sphere of energy efficiency, energy modelling using BEM platform of large buildings and companies owners is planted. The reason is that a properly done accomplishment can help to get off expensive procedures, for example the cost of energy investigation in Austria is $10000 €$, and Romania $200000 €$.

\footnotetext{
*Corresponding author: aljurgaitis@gmail.com
} 


\section{Thermal imaging inspection during assessing the quality of construction products}

Thermal imaging inspection is a non-destructive method of diagnostics and control of construction, installation, repair works, that allows to monitor the object during the operational phase. Thermal imaging helps to identify different defects such as cracks in the walls, high permeability of joints, it also allows to establish zones of heat loss, to eliminate expedites deterioration of the structure and to determine the effective operation of the entire construction. The process of thermal imaging examination is carried out as follows: first, the internal scanning of the object (walls, window blocks, doorways, heating systems) needs to be done, then the external parts of the building (roof, facade, roof structure) are examined. After that the specialists use this data and form the thermograms, that help to set the degree of danger of defects, their location and the reasons of their appearing. Also, the specialists create a detailed report on the results of the investigation work and define the set of measures to eliminate all the defects and problems.

Nowadays, there are several methods that determine the energy efficiency of buildings and structures, the main Russian documents and international standards that establish the requirements for carrying out these methods are reflected in table 1 .

Table 1. Regulatory framework for energy audit.

\begin{tabular}{|c|c|c|c|}
\hline & Title & Russia & International Practice \\
\hline 1 & $\begin{array}{c}\text { Basic } \\
\text { document }\end{array}$ & $\begin{array}{l}\text {-Federal Law of } 23.11 .2009 \text { No. } 261- \\
\text { FZ "On Energy Saving and Energy } \\
\text { Efficiency Improvment and the } \\
\text { Introduction of Amendments to } \\
\text { Certain Legislative Acts of the } \\
\text { Russian Federation" }\end{array}$ & $\begin{array}{c}\text { - ISO 50001:2018 "Energy management" } \\
\text { - BS EN 16247-1:2012 } \\
\text { "Energy audits. General requirements" } \\
\text { - ISO 14001:2015 "Environmental } \\
\text { management systems- Requirements with } \\
\text { guidance for use" }\end{array}$ \\
\hline 2 & $\begin{array}{l}\text { Thermal } \\
\text { images }\end{array}$ & $\begin{array}{l}\text { - MDS 23-1.2007 "Methodological } \\
\text { guidelines on the integrated heat } \\
\text { technical inspection of external } \\
\text { enclosure structures using the thermal } \\
\text { imaging equipment" } \\
\text { - GOST 26254-84 "Methods for } \\
\text { determination of thermal resistance of } \\
\text { enclosing structures" }\end{array}$ & $\begin{array}{c}\text { ISO 13790:2004 } \\
\text { "Thermal performance of buildings - } \\
\text { Calculation of energy use for space heating" } \\
\text { DIN EN 13187 } \\
\text { "Thermal performance of buildings - } \\
\text { Qualitative detection of thermal irregularities } \\
\text { in building envelopes - Infrared method" }\end{array}$ \\
\hline 3 & $\begin{array}{l}\text { Water } \\
\text { leakage } \\
\text { testing }\end{array}$ & $\begin{array}{l}\text { - GOST 33792-2016 "Curtain welling. } \\
\text { Methods of determination of alrand } \\
\text { water transmission “ }\end{array}$ & $\begin{array}{c}\text {-AAMA 501.2-15 “Quality Assurance and } \\
\text { Diagnostic Water Leakage Field Check of } \\
\text { Installed Storefronts, Curtain Walls, and } \\
\text { Sloped Glazing Systems" } \\
\text { - ASTM E2128 "Standard Guide for } \\
\text { Evaluating Water Leakage of Building Walls" } \\
\text { - AAMA 502-12 "Voluntary Specification for } \\
\text { Field Testing of Newly Installed Fenestration } \\
\text { Products" } \\
\text { And e.t.c. }\end{array}$ \\
\hline 4 & $\begin{array}{l}\text { Blower } \\
\text { Door }\end{array}$ & $\begin{array}{l}\text { - GOST 31167-2009 "Buildings and } \\
\text { structures. Methods for determination } \\
\text { of air permeability of building } \\
\text { envelopes in field conditions" }\end{array}$ & $\begin{array}{l}\text { - ASTM E182-11(2017) "Standard Test } \\
\text { Methods for Determining Airtightness of } \\
\text { Buildings Using an Orifice Blower Door" }\end{array}$ \\
\hline 5 & $\begin{array}{l}\text { Air leakage } \\
\text { rate }\end{array}$ & $\begin{array}{l}\text { - GOST } 31167-2009 \text { "Buildings and } \\
\text { structures. Methods for determination } \\
\text { of air permeability of building } \\
\text { envelopes in field conditions" }\end{array}$ & $\begin{array}{c}\text { - ASTM E1186-17 "Standard Practices for Air } \\
\text { Leakage Site Detection in Building Envelopes } \\
\text { and Air Barrier Systems" } \\
\text { - ASTM E783-02(2010) "Standard Test } \\
\text { Method for Field Measurement of Air } \\
\text { Leakage Through Installed Exterior Windows } \\
\text { and Doors" }\end{array}$ \\
\hline
\end{tabular}


Comparison of Russian and international documents draws the following conclusion: foreign experience demonstrates a more detailed and structured approach to the problem of energy efficiency of buildings and structures.

The most favorable period to determine the heat loss in the construction is the heating period - the temperature difference increases and the heat flow in the heated building tends outwards, that is why the areas with high thermal conductivity are easier to identify. The most appropriate periods to fix the results in different counters are shown in table 2 .

Table 2. The most favourable period to determine the heat loss.

\begin{tabular}{|c|c|}
\hline Country & Months (period) \\
\hline Russia & The end of October - the beginning of April \\
\hline The United Kingdom & December - March \\
\hline Germany & November - March \\
\hline Canada & The end of October - the beginning of April \\
\hline
\end{tabular}

Widely used the measuring machine, named Blower door, which creates a reduced pressure in the room and, as consequence, leads the cold air flows get into the building.

A comparative analysis of thermograms was held during a thermal imaging survey. There were several types of buildings (panel, modular, brick and wooden buildings) and each of them were scanned before using Blower Door and after using it [9]. All results are shown in table 4. A comparison of the results showed that it would be more effective to do investigation work with the help of Blower Door to obtain a more accurate and reliable result in determining critical structural defects. But the regulatory Russian Federation framework does not provide for the mandatory use of this thermal non-destructive testing method. Thus, the assignment of the energy efficiency class requires taking into account the possible error in the measurement results in the method of thermal imaging.

There are three conditions for the investigation of the building. They are the natural condition, the condition of low and high air pressure in the room [10-12] (table 3).

Table 3. Three air conditions.

\begin{tabular}{|c|c|c|c|}
\hline & $\begin{array}{l}\text { Air pressure } \\
\text { condition }\end{array}$ & Survey conditions & The subject of the inspection \\
\hline 1 & $\begin{array}{l}\text { Natural } \\
\text { condition } \\
\text { (operating } \\
\text { mode) }\end{array}$ & $\begin{array}{l}\text { The difference between the air inside and } \\
\text { outside } \geq 10^{\circ} ; \\
\text { external part of the house is not exposed } \\
\text { to overheating sunlight; } \\
\text { no rain; } \\
\text { moderate wind. }\end{array}$ & $\begin{array}{l}\text { Inspection of the interior surface; } \\
\text { inspection of the exterior of the } \\
\text { building; identification of cold } \\
\text { bridges }\end{array}$ \\
\hline 2 & $\begin{array}{l}\text { Reduced air } \\
\text { pressure }\end{array}$ & $\begin{array}{l}\text { Stick with duct tape the places with } \\
\text { possible blow; } \\
\text { close the vents, stone holes, hoods; } \\
\text { set the Blower Door at the entrance door; } \\
\text { create a difference of pressure at 50-60 } \\
\text { PA. }\end{array}$ & $\begin{array}{l}\text { Re-examination of internal } \\
\text { structures; } \\
\text { detection of hidden defects }\end{array}$ \\
\hline 3 & $\begin{array}{l}\text { Increased } \\
\text { air pressure }\end{array}$ & $\begin{array}{l}\text { Create a difference of pressure at 50-60 } \\
\qquad \mathrm{MPa}\end{array}$ & $\begin{array}{l}\text { Re-inspection of external } \\
\text { surfaces; detection of defects in } \\
\text { the roof and facades. }\end{array}$ \\
\hline
\end{tabular}


Table 4. The comparison of survey results with the using of thermal imaging cameras and Blower Door.

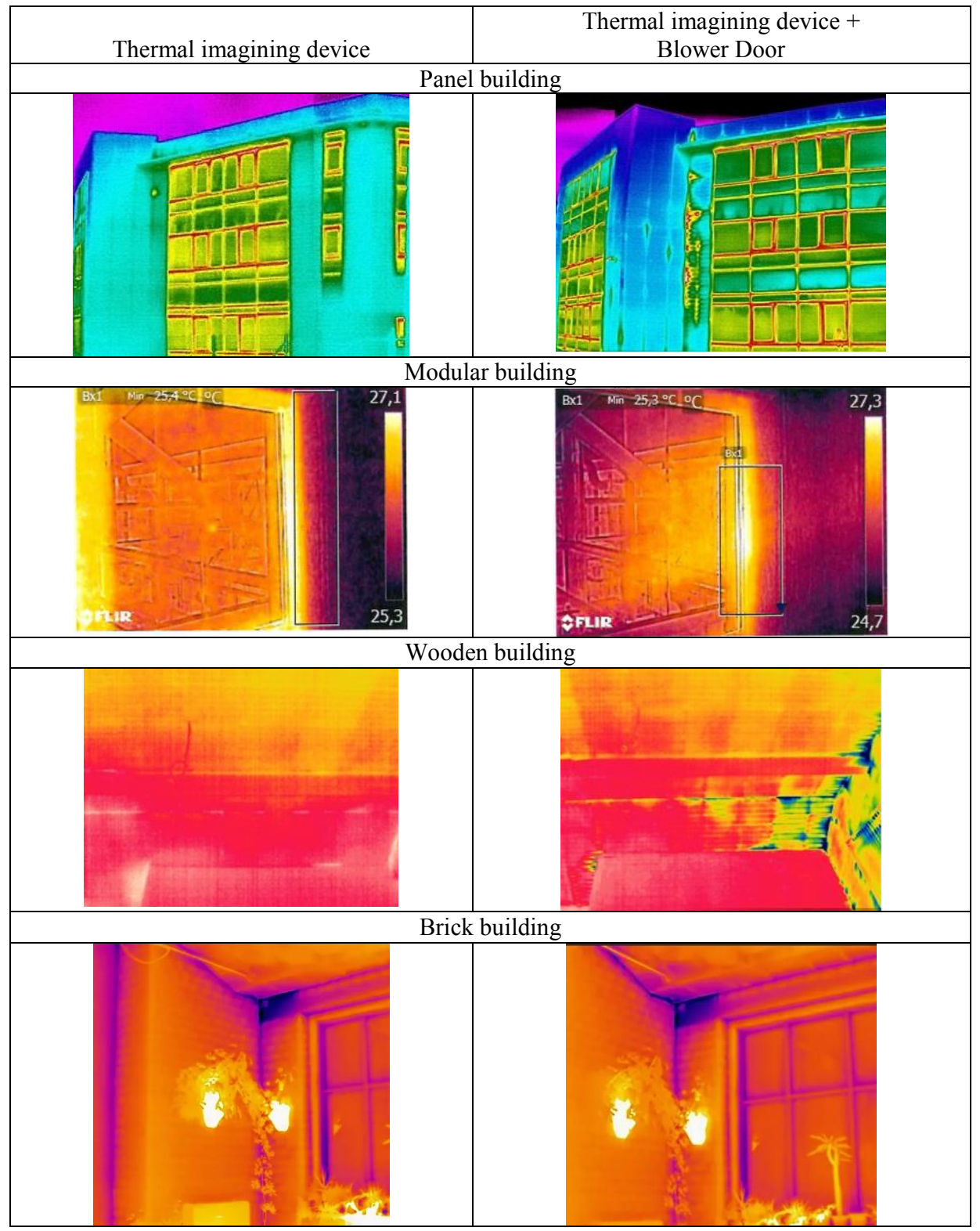

\section{The effectiveness of the cooperative using thermal imaging tools and diagnostic equipment Blower Door}

Particular attention should be paid to the parameter of air permeability of the enclosing structure. The joint implementation of television shooting with testing the building envelope for breathability is described in the European standard EN-13187 "Thermal performance of buildings - qualitative detection of thermal irregularities in building 
envelopes - infrared method" [6]. The use of this method with the help of Blower Door assuredly identifies possible defects in the air barrier. The data obtained during the measurements should be compared with the current construction standards for air permeability, described in SNiP 23-02-2003 "Thermal protection of buildings", to identify violations at the initial stage and eliminate them [7].

European standards are the base for Russian standard GOST R 54852-2011 " Buildings and structures. The method of thermal imaging quality control of thermal insulation of enclosing structures" [8]. It is written in item 9.10 that during identification of defects in the place of joining of wall panels must be checked on air permeability. When forming the report (Appendix B, item 13) it is necessary to reflect air pressure drop both on the windward, and leeward side. The method of thermal imaging quality control of thermal insulation of enclosing structures " takes into account European standards. In item 9.10 it is written that at identification of defects in the place of joining of wall panels check on air permeability in a design is obligatory. When forming the report (Appendix B, item 13), it is necessary to reflect air pressure drop both on the windward and leeward side.

During the collaboration work of thermal imaging and Blower Door technology the following conclusions were made:

- the created pressure drop allows to conduct inspection more carefully;

- areas of high filtration help easier to find places of defects;

- surveys can be held at any time of the year, regardless of the ambient temperature;

- surveys can be carried out at all stages of the building life cycle.

After the analysed data is obtained, the multiplicity of air exchange and air permeability index need to be measured. The multiplicity of air exchange is a value, that reflects the amount of complete replacement of air with a new one for 6 minutes [10].

$$
n_{50}=\frac{Q}{V_{\text {room }}} ;
$$

where $Q$ - is the measured air flow, $V_{\text {room }}$ - is the volume of the measured room.

Normative values $n_{50}$ for the Russian Federation and Western Europe are shown in the table 5:

Table 5. Normative values of ventilation rate.

\begin{tabular}{|c|c|c|c|}
\hline \multirow{2}{*}{} & \multirow{2}{*}{ Type of building } & \multicolumn{2}{|c|}{ Normative values of air exchange rate $n_{50}, \mathrm{~h}$} \\
\cline { 3 - 4 } & $\begin{array}{c}\text { Russian Federation } \\
\text { SNiP 23-02-2003 [7] }\end{array}$ & Europe EnEV [11] \\
\hline 1 & Natural ventilation & $\leq 4$ & $\leq 3.0$ \\
\hline 2 & $\begin{array}{c}\text { Mechanical } \\
\text { ventilation }\end{array}$ & $\leq 2$ & $\leq 1 ., 5$ \\
\hline 3 & Passive house & $\leq 0.6$ & $\leq 0.6$ \\
\hline
\end{tabular}

The comparative table on the main characteristics of the energy audit and energy efficiency index in Russia, the USA and Europe was drawn up to visualize the difference between these countries (table 6). 
Table 6. Comparative analysis of energy audit in Russia, the USA and Europe.

\begin{tabular}{|c|c|c|}
\hline Russia & USA & Europe \\
\hline \multicolumn{3}{|c|}{ Classification of buildings according to energy efficiency index } \\
\hline -is set only for apartment building [5] & \multirow{7}{*}{ 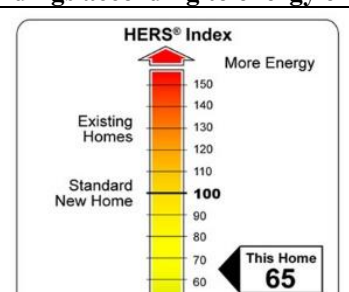 } & Building Energy Efriciency Rating \\
\hline & & for Public Builitinger \\
\hline & & \\
\hline 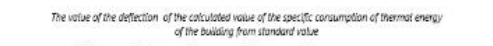 & & \\
\hline 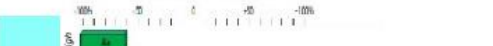 & & B $26-50$ \\
\hline & & \\
\hline \multirow{5}{*}{ 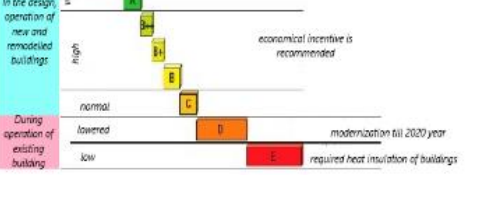 } & & 100 would be typial \\
\hline & \multirow{4}{*}{$\begin{array}{l}\text { Zero Energy } \\
\text { Home }\end{array}$} & E \\
\hline & & \\
\hline & & \\
\hline & & Less enengy eficicant \\
\hline \multicolumn{3}{|c|}{ Contractor } \\
\hline $\begin{array}{l}\text {-during setting into operation is done } \\
\text { by members of State Housing } \\
\text { Inspectorate, further-the developer with } \\
\text { subcontract certificated organization }\end{array}$ & $\begin{array}{l}\text { Energy audit contractors. } \\
\text { The Union of Military } \\
\text { engineers (for military } \\
\text { buildings) }\end{array}$ & $\begin{array}{l}\text { Independent certificated } \\
\text { specialists (work experience } \\
2-5 \text { years with diplomas I-III } \\
\text { classes), or organizations } \\
\text { (after the recognition of } \\
\text { government authorities is } \\
\text { need), or collaborator of State } \\
\text { Supervision [2] }\end{array}$ \\
\hline \multicolumn{3}{|c|}{ Procedure for the carrying out of energy audit } \\
\hline $\begin{array}{l}\text {-preparation of building } \\
\text {-external examination } \\
\text {-examination of constructions } \\
\text {-preparation of report about defects } \\
\text { and guidelines of clearing }\end{array}$ & $\begin{array}{l}\text {-site assessment and } \\
\text { preliminary audit (evaluation } \\
\text { of accounts for the last } 2 \\
\text { years and a brief inspection of } \\
\text { the building) } \\
\text {-energy survey and } \\
\text { engineering analysis } \\
\text { (selection of small } \\
\text { investments in correction, } \\
\text { according to the energy } \\
\text { consumption of the house) } \\
\text { - a detailed analysis of } \\
\text { capital-intensive revisions } \\
\text { (sometimes referred to as an" } \\
\text { investment class " audit) } \\
\text { provides guidance and } \\
\text { financial analysis of major } \\
\text { capital investments }\end{array}$ & $\begin{array}{c}\text { - primary inspection of } \\
\text { the object } \\
\text { - analysis of } \\
\text { documentation on energy } \\
\text { consumption for the last } 3 \\
\text { years (excluding new } \\
\text { construction) } \\
\text { - thermal imaging } \\
\text { inspection and application of } \\
\text { Blower Door technology } \\
\text { (alternative control methods } \\
\text { for commercial and industrial } \\
\text { buildings) } \\
\text { - preparation of } \\
\text { conclusion and } \\
\text { recommendations on energy } \\
\text { efficiency (energy } \\
\text { management) [3] }\end{array}$ \\
\hline \multicolumn{3}{|c|}{ Periodicity } \\
\hline $\begin{array}{c}\text {-during setting into operation } \\
\text {-the second not later than } 3 \text { months } \\
\text { left till } 5 \text { years after the date of issue of } \\
\text { energy efficiency report from State } \\
\text { Housing } \\
\text {-at the initiative of the owners (house } \\
\text { Manager) no more than } 1 \text { time per year }\end{array}$ & & $\begin{array}{c}1 \text { time per } 4 \text { years for } \\
\text { Large Electricity Consumers } \\
\text { or when improvement notice } \\
\text { is addressed to organizations } \\
\text { with less energy consuming } \\
\text { [2] }\end{array}$ \\
\hline \multicolumn{3}{|c|}{ Paying/free basis } \\
\hline On a profit-making basis & $\begin{array}{l}\text { On a profit-making basis } \\
\text { (approximately } 10000 \$ \text { ) }\end{array}$ & $\begin{array}{c}\text { For LEC it is a paid } \\
\text { service (tax), which is used for } \\
\text { energy survey of small } \\
\text { organizations [4] }\end{array}$ \\
\hline \multicolumn{3}{|c|}{ Types of buildings which are not are not subject to energy efficiency requirements } \\
\hline The list from paragraph 5 art. 11 [1] & & Manufactured buildings \\
\hline
\end{tabular}




\section{Conclusion}

Therefore, a detailed and thoughtful approach to energy audit and thermovision inspection of buildings is necessary, which is proved by international experience. Domestic regulatory documents contain only a descriptive part of the possible problems that can be encountered in practice, bypassing the procedure and classification for assigning buildings (except for apartment buildings) class of energy efficiency. Energy audit is a complex and necessary stage of operational lifetime of each building, especially for large energy consumers. In connection with this, it is necessary to create not only a common order of procedures for all, but also structured by a type of building and energy consumption. The actual purpose of further research is the formation of a more detailed method of defect identification of buildings and structures upkeep of buildings, taking into account the constructive features and functional purpose, as well as taking into account the large-scale factor that allows to approach the issue of determining the criticality of violations of energy efficiency in term of system analysis.

\section{References}

1. Russian Federal Law No. 261-FZ

2. T. Serrenho, P. Bertoldi, C. Cahill, Survey of energy audits and energy management systems in the Member States (Ricardo Energy \& Environment, US, 2015)

3. R. Eaton, M. Johnson, A Study on Energy Efficiency in Enterprises: Energy Audits and Energy Management Systems (Ricardo Energy \& Environment, US, 2015)

4. I. Kudrenickis, G. Klavs, New Latvian Energy Efficiency Law and Alternative measures (Institute of Physical Energetics Energy system analyses and optimisation department, Latvia, 2016)

5. European Norm EN-13187

6. Russian Federation Standard SNiP 23-02-2003

7. Russian Federation Standard GOST R 54852-2011

8. I. Potekhin, V. Mischenko, A. Mottaeva, A. Zheltenkov, E3S Web of Conferences 33, 03020 (2018) doi: 10.1051/e3sconf/20183303020

9. V.M. Svistunov, N.K. Pushnikov, Heating, ventilation and air conditioning of objects of agro-industrial complex and housing and communal services (Ricardo Energy \& Environment, US, 2012)

10. S. Kunkel, E. Kotonasiou, Indoor air quality thermal comfort and daylight. Analysis of residential building regulations in eight EU member states (Ricardo Energy \& Environment, US, 2015)

11. T. Nemova, K. Trofimov, Methodical instructions to practical work. Thermal diagnostic of the building (Ricardo Energy \& Environment, US, 2015)

12. M. Scheffer, M. Konig, T. Engelmann, L. C. Tagliabue, A. L. C. Ciribini, S. Rinaldi, M. Pasetti, 2018 IEEE International Workshop on Metrology for Industry 4.0 \& IoT,16-18 April 2018, Brescia, Italy (2018). DOI: 10.1109/METROI4.2018.8428349 